\title{
CETACEAN STRANDINGS IN TASMANIA FROM FEBRUARY 1978 TO MAY 1983
}

by T.J. McManus ${ }^{1}$, J.E. Wapstra ${ }^{2}$, E.R. Guiler ${ }^{3}$, B.L. Munday ${ }^{4}$, and D.L. Obendorf $f^{4}$

${ }^{1}$ Department of Agriculture, Falmouth, ${ }^{2}$ National Parks and Wildilife Service, Sandy Bay, 3 Department of Zoology, University of Tasmania, Sandy Bay, and

4 Department of Agriculture, Mt Pleasant Laboratories, Launceston South, Tasmania.https://doi.org/10.26749/rstpp.118.117

\section{ABSTRACT}

(with one table, one text-figure and five plates)

MCMANUS, T.J., WAPSTRA, J.E., GUILER, E.R., MUNDAY, B.L. and OBENDORF, D.L., 1984 (31

viii): Cetacean strandings in Tasmania from February 1978 to May 1983. Pap. Proc.

R. Soc. Tasm., 118: 117-135, pls 1-5. ISSN 0080-4703. Department of Agriculture,

Falmouth and Mt Pleasant, Tasmania, National Parks and Wildlife Service, Hobart and University of Tasmania, Hobart, Tasmania.

This paper presents a summary of 46 recent whale strandings involving 13 species and 497 animals, as well as six strandings not included in the previous summary by Guiler (1978). Two new species are added to the 22 previously recorded for Tasmania. Details of rescue operations, including an evaluation of current procedures, are given. Causes of the stranding phenomenon are discussed with particular reference to events in Tasmania. Results of pathological examinations are given, together with analyses of heavy metal and pesticide residue in tissues.

\section{INTRODUCTION}

Records of strandings of cetaceans around Tasmania's coastline date from the mid1800s (Scott 1942, Davies 1963, Guiler 1978). In recent years the frequency of stranding reports has increased, possibly as a consequence of easier access to remote stretches of coastline, and an enhanced public and government awareness of cetaceans. This paper presents an update on Tasmanian strandings from 1945-78 reported by Guiler (1978). Twentytwo cetacean species are listed as having stranded in Tasmanian waters since records began (Guiler 1978), although the evidence for some of these is scanty. This paper adds two species, Sei Whale Balaenoptera borealis and Southern Bottlenosed Whale Hyperoodon planifrons, to the previous record.

As elsewhere, cetacean strandings on Tasmanian shores are either single, multiple or mass, the latter involving up to 300 individuals. Several possible explanatory theories have been proposed for these events (Bergin 1978, Geraci \& St Aubin 1979, Cordes 1982). Single animals were generally assumed to have beached themselves because they were sick or injured. However, recent studies in Tasmania indicate that this is not always so (Munday et al. 1982). Occasionally topographical factors or turbulent weather conditions are involved whereby individuals or even groups become "lost" particularly during spring-tides, leaving themselves hopelessly stranded. Other factors such as severe ear parasitism may also sometimes contribute to strandings (Geraci \& St Aubin 1979). In some single strandings the whale had died at sea and was washed ashore.

From 1978 to 31 May 1983, 46 cetacean strandings involving 13 species and 497 animals were recorded in Tasmania. These are summarised in table 1. Because the occurrence of "spring" tides associated with the new and full moon is frequently cited as a factor in strandings, where applicable the nearest dates of these two lunar phases are included. The relationship between phases of the moon and "spring" and "neap" tides, is an extremely complex one. "Spring" tides do not occur simultaneously with their respective lunar phase, but approximately one to five days later depending on the locality and time of year. The actual number of "spring" tides month by month also varies, as does their height. In table 1, where a particular stranding might conceivably relate to a lunar-induced "spring" tide, the date of the relevant moon phase is underlined. 
TABLE 1

CHRONOLOGICAL SUMMARY OF STRANDINGS, FEBRUARY 1978-MAY 1983

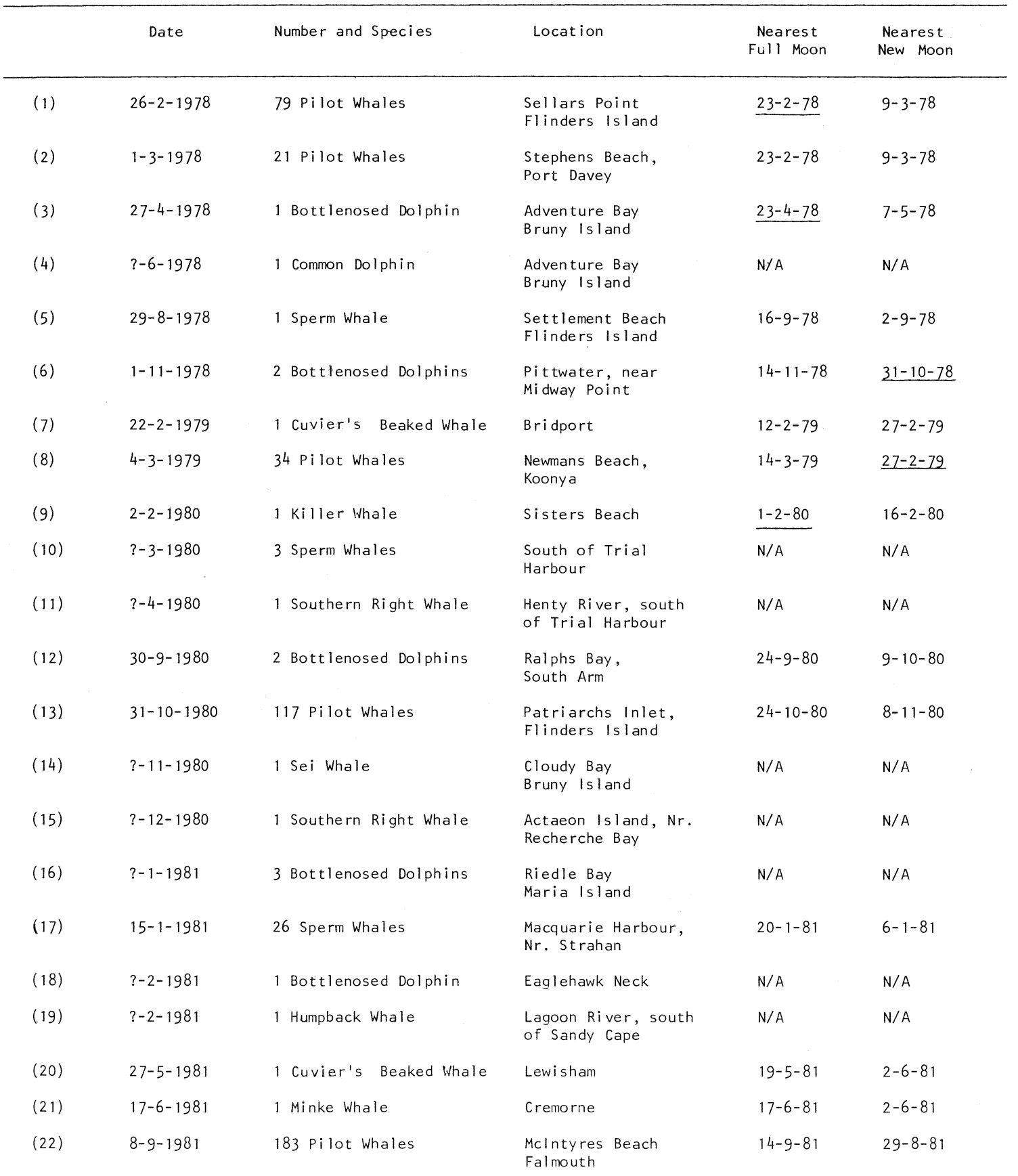


T.J. McManus, J.E. Wapstra, E.R. Guiler, B.L. Munday and D.L. Obendorf

\begin{tabular}{|c|c|c|c|c|c|}
\hline (23) & $10-9-1981$ & 1 Pygmy Right Whale & West Beach, Stanley & $14-9-81$ & $29-8-81$ \\
\hline (24) & $25-9-1981$ & 2 Sperm Whales & $\begin{array}{l}\text { Fotheringate Bay, } \\
\text { Flinders Is land }\end{array}$ & $14-9-81$ & $28-9-81$ \\
\hline (25) & $27-12-1981$ & 1 Gray's Beaked Whale & $\begin{array}{l}\text { Nine Mile Beach, } \\
\text { Swansea }\end{array}$ & $11-12-81$ & $26-12-81$ \\
\hline (26) & $3-1-1981$ & 3 Strap-toothed Whales & $\begin{array}{l}\text { Cloudy Bay, } \\
\text { Bruny Is land }\end{array}$ & $10-1-82$ & $26-12-81$ \\
\hline (27) & $7-1-1982$ & 51 Pilot Whales & Macquarie Harbour & $10-1-82$ & $26-12-81$ \\
\hline (28) & $8-1-1982$ & 1 Bottlenosed Dolphin & $\begin{array}{l}\text { Ocean Beach, } \\
\text { Strahan }\end{array}$ & $10-1-82$ & $26-12-81$ \\
\hline (29) & $23-1-1982$ & 1 Sperm Whale & $\begin{array}{l}\text { Perkins Bay, } \\
\text { Stanley }\end{array}$ & $10-1-82$ & $25-1-82$ \\
\hline (30) & $26-1-1982$ & 14 Sperm Whales & $\begin{array}{l}\text { Ocean Beach, } \\
\text { Strahan }\end{array}$ & $8-2-82$ & $25-1-82$ \\
\hline (31) & $9-2-1982$ & 9 Sperm Whales & $\begin{array}{l}\text { Perkins Bay, } \\
\text { Stanley }\end{array}$ & $8-2-82$ & $25-1-82$ \\
\hline (32) & $9-3-1982$ & 2 Common Dolphins & $\begin{array}{l}\text { Little Taylors Bay, } \\
\text { Bruny Island }\end{array}$ & $10-3-82$ & $24-2-82$ \\
\hline (.33) & $1-4-1982$ & 1 Bottlenosed Dolphin & $\begin{array}{l}\text { Gorringes Beach } \\
\text { South Arm }\end{array}$ & $9-4-82$ & $25-3-82$ \\
\hline (34) & $14-6-1982$ & 1 Pygmy Right Whale & $\begin{array}{l}\text { West Inlet } \\
\text { Stanlèy }\end{array}$ & $7-6-82$ & $21-6-82$ \\
\hline (35) & $13-9-1982$ & 1 Pygmy Right Whale & $\begin{array}{l}\text { Darlington, } \\
\text { Maria Island }\end{array}$ & $3-9-82$ & $17-9-82$ \\
\hline (36) & $1-10-1982$ & 2 Bottlenosed Dolphins & $\begin{array}{l}\text { Pittwater, near } \\
\text { Midway Point }\end{array}$ & $3-10-82$ & $17-9-82$ \\
\hline (37) & $?-10-1982$ & 1 Sperm Whale & Ringarooma Bay & $\mathrm{N} / \mathrm{A}$ & $\mathrm{N} / \mathrm{A}$ \\
\hline (38) & $5-1-1983$ & 1 Pygmy Right Whale & $\begin{array}{l}\text { Trumpeter Bay, } \\
\text { Bruny Is land }\end{array}$ & $30-12-82$ & $14-1-83$ \\
\hline （39） & $14-1-1983$ & 1 Sperm Whale & $\begin{array}{l}\text { Temma, west } \\
\text { coast }\end{array}$ & $29-1-83$ & $14-1-83$ \\
\hline$(40)$ & $14-1-1983$ & 1 Pilot Whale & $\begin{array}{l}\text { Howells Point, } \\
\text { Maria Is land }\end{array}$ & $29-1-83$ & $14-1-83$ \\
\hline (41) & $14-1-1983$ & 2 Strap-toothed Whales & $\begin{array}{l}\text { Cape Portland, } \\
\text { north-east coast }\end{array}$ & $29-1-83$ & $14-1-83$ \\
\hline$(42)$ & $24-1-1983$ & 1 Bottlenosed Dolphin & $\begin{array}{l}\text { Seven Mile Beach, } \\
\text { southern Tasmania }\end{array}$ & $29-1-83$ & $14-1-83$ \\
\hline (43) & $26-1-1983$ & 1 Pygmy Right Whale & West Beach, Stanley & $29-1-83$ & $14-1-83$ \\
\hline$(44)$ & $?-1-1983$ & 1 Strap-toothed Whale & $\begin{array}{l}\text { Plain Place Beach, } \\
\text { Triabunna }\end{array}$ & N/A & $\mathrm{N} / \mathrm{A}$ \\
\hline (45) & $4-2-1983$ & 15 Common Dolphins & $\begin{array}{l}\text { Ralphs Bay } \\
\text { South Arm }\end{array}$ & $29-1-83$ & $13-2-83$ \\
\hline (46) & $19-4-1983$ & 1 Sperm Whale & $\begin{array}{l}\text { Prion Beach, } \\
\text { south coast }\end{array}$ & $13-4-83$ & $27-4-83$ \\
\hline
\end{tabular}


of the 46 strandings, 16 were discovered and reported in time for rescue operations to be mounted. Since 1981, rescues in Tasmania have become increasingly efficient and successful as a result of improved planning and co-operation between the National Parks and Wildlife Service and other government authorities and volunteer organisations. The paper describes individual rescues in some detail and discusses aspects which are of importance to the development and refinement of contingency plans for whale rescues, locally and elsewhere.

\section{DETAILS OF INDIVIDUAL STRANDINGS}

The following is a summary of cetacean strandings to 31 May 1983 and follows on from Guiler (1978). Descriptions of events are arranged in taxonomic order according to Watson (1981) and sequentially within each species. For each event, the stranding number used in the chronological summary of table 1, is given except for strandings additional to the previous summary for $1945-78$ in Guiler (1978). These numbers are also used in figure 1 which plots the locations of strandings. Certain additional information, including standard measurements (if available), site topography, sea conditions and tides, unless essential for an understanding of the events described, are given in an Appendix which may be obtained from the editor.

In the few instances which have not been investigated on site by one or more of the authors, descriptions are based on detailed reports submitted and identifications confirmed from photographs or clear descriptions of distinctive features of the whales involved.

\section{Baleen Whales (Mysticeti)}

Southern Right Whale Balaena glacialis

Henty River, south of Trial Harbour, April 1980 (No.11)

The carcass was badly decomposed when discovered.

Actaeon Island, Recherche Bay, November/December 1980 (No.15)

This animal was discovered long after any useful examination was possible. Its length $-7 \mathrm{~m}$, indicates it was a juvenile, but no cause of the stranding could be elicited. The two Southern Right Whale strandings cited in this paper are the first reported in Tasmania for more than a century.

Pygmy Right Whale Caperea marginata

Fotheringate Bay, Flinders Island, May 1975

A mother and calf, no other details available.

West Beach, Stanley, 10 September 1981 (No.23)

Details of this animal are given in a recent paper in these proceedings (Munday et al. 1982), and in the Appendices herewith. It was a pregnant female in apparent good health $6.45 \mathrm{~m}$ long, containing a $380 \mathrm{~mm}$ female foetus. There was no significant pathology.

West Inlet, Stanley, 14 June 1982 (No.34)

This was also a pregnant female which stranded $4 \mathrm{~km}$ south of stranding number 23 . The most notable feature was that despite being only $6 \mathrm{~m}$ long itself, this whale contained a full-term foetus measuring $2 \mathrm{~m}$, i.e. one third of its mother's length. It too was female. Rescue attempts failed and the animal died 16 hours after stranding. No pathological lesions were detected on post mortem examination.

Darlington, Maria Island, 13 September 1982 (No.35)

The only male among the four whose sex was determined. It was quite large for the species being $6.09 \mathrm{~m} 1$ ong, and its skin surface bore numerous circular scars, some recent, some old, on the lower sides and ventral abdomen. These scars were 40-50 mm in diameter on average, and occurred either singly or in multiples of two or three. They are regular lesions on adult Pygmy Right Whales stranded in Tasmania, and are consistent with the predatory effects of "cookie-cutter" sharks, e.g. Isistius brasiliensis, as described by Watson (1981). 
T.J. McManus, J.E. Wapstra, E.R. Gui 1er, B.L. Munday and D.L. Obendorf
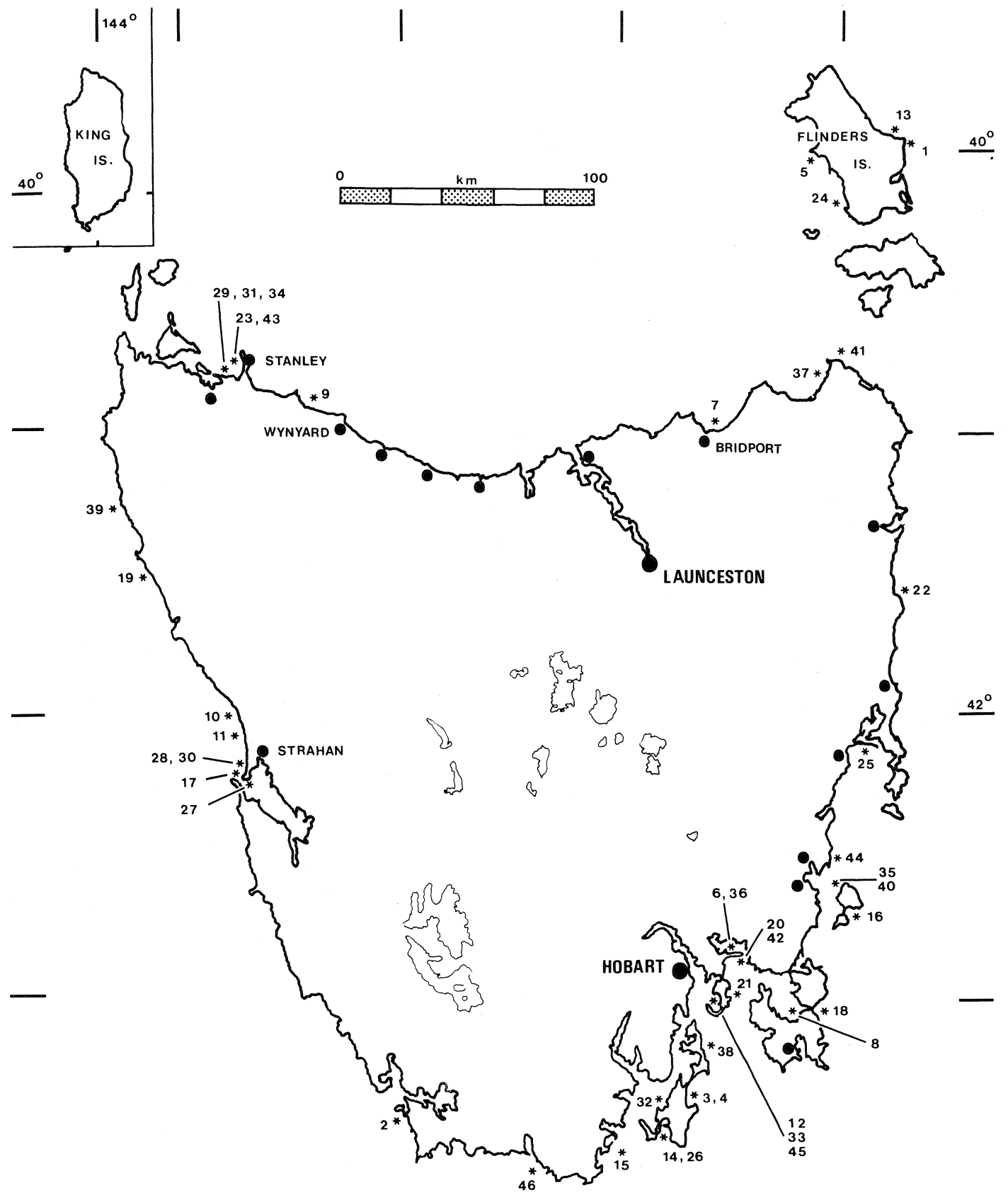

\begin{tabular}{ll|l|l|l|l}
$\left.\right|_{145^{\circ}}$ & $\mid$ & $\left.\right|_{140^{\circ}}$ & $\mid$
\end{tabular} 
This whale came ashore adjacent to the base of the jetty in Darlington Bay at 7.30 p.m. It appeared weak and died at noon the next day whilst rescue efforts were in progress. Due to its proximity to a popular tourist venue, only limited post mortem sampling was possible.

Trumpeter Bay, North Bruny Island, 5 January 1983 (No.38)

A rare instance of a baleen whale being returned successfully to the sea. This was achieved by a local resident who used the sand-filled scoop of a front-end loader to push the animal off the beach. After initial disorientation, during which the equipment was used to prevent re-beaching, the whale headed slowly out to sea. It was last observed swimming strongly beyond the confines of the bay. The animal was estimated to measure $5 \mathrm{~m}$, but its sex was not determined.

West Beach, Stanley, 26 January 1983 (No.43)

A female, approximately $5 \mathrm{~m}$ in length, with no obvious abnormalities. Unfortunately the head had been removed by a member of the public before postmortem examination began, but inspection of internal organs revealed no significant pathology. She was not pregnant. Samples were collected for heavy metal and insecticide residue tests.

The Pygmy Right Whale is by far the most common baleen whale stranded in Tasmanian waters. The five new records in this paper continue the sequence of regular reports extending back over 50 years (Scott 1942, Davies \& Guiler 1957, Guiler 1978).

Minke Whale Balaenoptera acutorostrata

Cremorne, 17 June 1981 (No.21)

This animal was a newly born female calf, $2.24 \mathrm{~m}$ long, still bleeding from its umbilicus. As it appeared to be in good condition, it was released in Frederick Henry Bay about $1.5 \mathrm{~km}$ offshore from the point of stranding, in the hope that it would rejoin its mother. However, early next day the whale was found restranded in virtually the same place and died shortly after. Two of the four previous strandings of the species also involved recently born calves and occurred during early winter, indicating that calving may take place in or close to Tasmanian waters (Guiler 1978).

Sei Whale Balaenoptera borealis

Cloudy Bay, South Bruny Island, October/November 1980 (No.14)

The first report of a Sei Whale stranding in Tasmania. It occurred at the southern end of the beach. The skull and baleen were collected from the decomposed carcass. The whale was a juvenile, approximately $7 \mathrm{~m}$ long.

Humpback Whale Megaptera novaeangliae

Lagoon River, $8 \mathrm{~km}$ south of Sandy Cape, February 1981 (No.19)

The carcass was decomposed and no other information is available.

Toothed Whales (Odontoceti)

Cuvier's Beaked Whale Ziphius cavirostris

Bridport, 22 February 1979 (No.7)

The animal was dead when discovered but apart from identification, was not examined closely.

Lewisham, 27 May 1981 (No.20; plate 1)

This whale had been reported in the vicinity for two days prior to stranding. Eventually it came alongside a rocky platform projecting into shallow water, belly down and facing landwards. Rescue efforts failed as boats or vehicles could not reach the site and the animal was too heavy to be moved manually. As the tide rose the whale attempted to free itself by violent thrashing but unfortunately drowned.

The whale was a male, $5.78 \mathrm{~m}$ long. It had many characteristic double-track scars criss-crossing its back and sides. These parallel scars result from fighting with other males, the distance between the lines being equivalent to the gap between the two conical teeth at the end of the lower jaw of males of this species (Watson 1981). It also had 
PLATE 1 - Isistius scars and characteristic double-track scars from fighting, Cuvier's Beaked Whale (No.20). Photo: A. Wapstra.

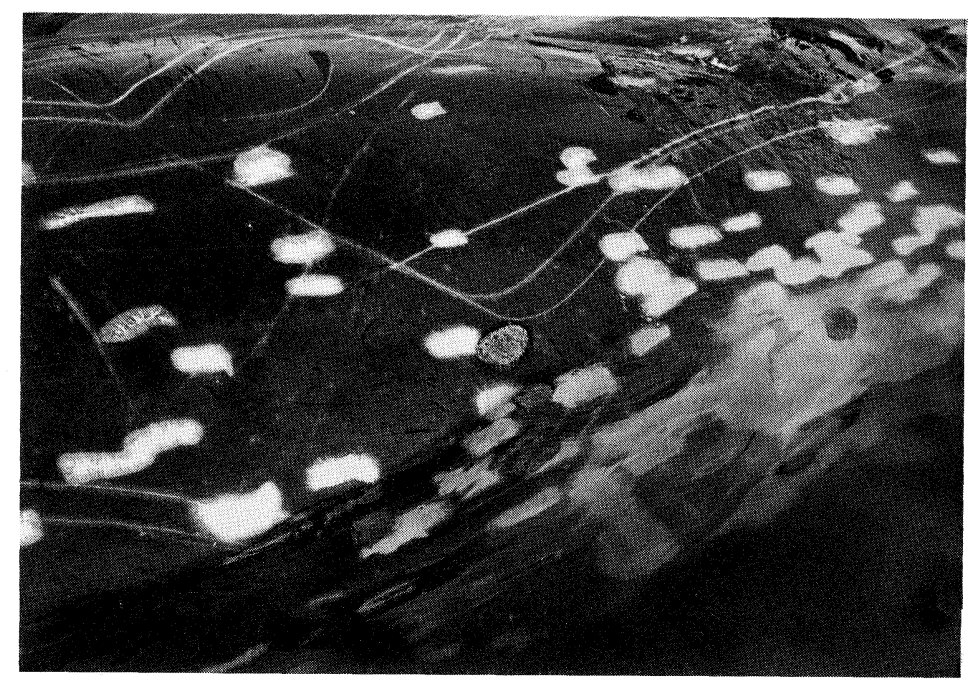

numerous round and oval scars similar to those caused by "cookie-cutter" sharks, as described by Watson (1981).

Both records conform with earlier ones (Guiler 1978) in that they are of single animals.

Southern Bottlenosed Whale Hyperoodon planifrons

Ocean Beach, Strahan, date unknown

This record is based on a large dried skull found by M. Schulz of Monash University on 25 February 1981 on Ocean Beach, near the entrance to Macquarie Harbour (Strahan). It was half covered by sand, perfectly clean and apparently older than the records presented in this paper. It was reported and collected in 1983 by which time some moss growth had occurred. Although the mandible was missing, the upper jaw and cranium were almost entire$1 \mathrm{y}$ intact, permitting positive identification. This is the first record of Southern Bottlenosed Whale in Tasmanian waters. The skull is described by Davis \& Guiler (1984).

Gray's Beaked Whale Mesoplodon grayi

Apple Orchard Point, Cape Barren Is1and, June/July 1972 able.

Identified from skull. Carcass decomposing when found, no other information avail-

Nine Mile Beach, Swansea, 27 December 1981 (No.25)

The animal was reported belatedly, precluding close examination except for identification from the skull. Although commonly stranded on New Zealand shores, this record is only the fourth for Tasmania.

Strap-Toothed Whale Mesoplodon Zayardi

Cloudy Bay, South Bruny Island, 3 January 1982 (No.26)

Three freshly dead females of similar length $(4.53,4.59$ and $4.86 \mathrm{~m})$. They were first observed swimming close inshore in very rough conditions the previous evening.

Cape Portland, approximately 14 January 1983 (No.41)

One large female whale was found dead on Little Musselroe Beach on 14 January and a small juvenile male was found washed up a few days later on the rocks of Lanoma Point, some $6 \mathrm{~km}$ to the west. A mother-calf relationship can only be speculative due to the differences in the dates and locations of the whales being discovered. Details of the stranding and skull description are given in Guiler (1984). 
Plain Place Beach, Triabunna, January 1983 (No.44)

The specimen was reported in May by a local resident who had first seen the carcass in March. At that time it was relatively intact and measured approximately $5.5 \mathrm{~m}$. Further local enquiries revealed that the animal had stranded in January. Examination of the remains showed that a section of the rostrum had been removed with a saw, presumably for its impressive teeth, but other skull features allowed positive identification of the species as well as its sex (male).

Sperm whale Physeter macrocephazus

Patriarchs Inlet, Flinders Island, 1975

Remains of three animals, no other information available.

Settlement Beach, F1inders Island, 29 August 1978 (No.5)

This stranding of a large animal was reported by Rounseve11 et al. (1981).

South of Trial Harbour, March 1980 (No.10)

Decomposing corpses of three animals.

Macquarie Harbour, Strahan, 15 January 1981 (No.17)

A mass stranding of 26 animals. The most interesting aspect of this event was that nine whales returned to deep water, five voluntarily and four with some assistance. Rounsevell et al. (1981) stated this to be the first Australian record of Sperm Whales leaving a mass stranding while others remained alive. Although one of them is known to have restranded and died, the fate of the other eight is unknown.

Fotheringate Bay, Flinders Island, about 25 September 1981 (No.24)

Two mature males, 16.0 and $16.2 \mathrm{~m}$ respectively, which had been dead for about two weeks. Advanced decomposition precluded detailed examination.

Perkins Bay, Stanley, 23 January 1982 (No.29)

An adult female $10.6 \mathrm{~m}$ long. Next day it evulsed a $4.1 \mathrm{~m}$ male calf. Difficult access to the site precluded pathological examination.

Ocean Beach, Strahan, about 26 January 1982 (No.30; plate 2)

A mass stranding of 14 animals. When discovered the carcasses had commenced to decompose and one female had either aborted or evulsed a $3.96 \mathrm{~m}$ male foetus. Abdominal cavities were ruptured and skin had blistered and extruded fat. Numerous whales had evidence of squid sucker marks on their bodies especially around their heads, a common phenomenon also mentioned by Rounsevel1 et $\alpha$. (1981), in reference to stranding number 17.

The sex ratio was three males to 11 females, the longest male being $14.30 \mathrm{~m}$ and the longest female $11.65 \mathrm{~m}$. Several jaws were collected for age determination but no further examination was possible.

Perkins Bay, Stanley, 9 February 1982 (No.31)

Nine animals were first observed swimming offshore in the shallows at about 6 p.m. approximately one hour prior to the second lowest spring ebb-tide for the month of February. They became stranded later that same evening but four of them were refloated by the high spring tide just after midnight and next morning only five whales remained - all adult females. Whether the escapees survived is not known; those remaining were all dead by the following evening.

Lengths ranged from $10.40 \mathrm{~m}$ to $11.25 \mathrm{~m}$. They rapidly decomposed in the summer sun and by the time a pathologist could reach the site, little could be deduced. A single post mortem was conducted and death was found to be due to drowning. Sections of skulls were collected for anatomical information and these are at Mt Pleasant Laboratories, Department of Agriculture, Launceston.

Ringarooma Bay, October 1982 (No.37)

Putrid carcass found some weeks after stranding. 
PLATE 2 - Sperm Whales beached at Strahan (No.30).

Photo: A. Wapstra.

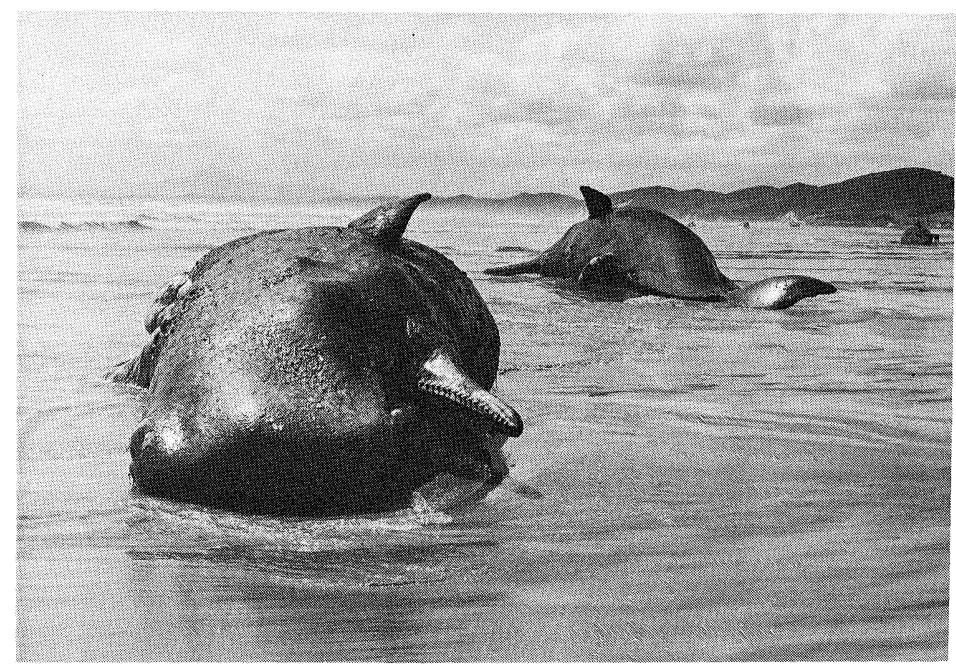

Temma, about 14 January 1983 (No.39)

Washed up dead according to local residents. It was an adult female, approximately $11.10 \mathrm{~m} \mathrm{long}$, and putrid when examined on 28 January.

Prion Beach, 19 April 1983 (No.46)

A single animal found freshly dead, rolling in the surf. Length estimated "25 feet", sex unknown. A feature was its unusual colour, said to be "nearly white".

Pilot Whale Globicephala melaena

Sellars Point, Flinders Island, about 26 February 1978 (No.1)

Mass stranding of 79 animals, which could not be examined until several days after the actual stranding by which time all the whales were dead and some partially buried. The majority were females two of which evulsed a foetus after stranding. They beached themselves on a sand spit extending off-shore from the Point, and when discovered were all facing in a northerly direction indicating an approach from the south between Babel Island - towards which the sand spit extends - and Flinders Island. The "spring" tide may well have had a bearing on this stranding.

Stephens Beach, Port Davey, about 1 March 1978 (No.2)

Mass stranding of 21 animals. All the whales were reported to be melanic.

Newmans Beach, Koonya, 4 March 1979 (No.8)

Mass stranding of 34 animals. A wide very shallow beach where the tide recedes about $400 \mathrm{~m}$ at full ebb, leaving numerous shallow pools capable of causing confused echolocation to whales passing over the area at high water. The sea beyond the ebb tide-line is also shallow. All the whales were stranded well up the beach just below the Zostera beds, by a receding "spring" tide. Despite rescue attempts all the whales eventually died.

Patriarchs Inlet, Flinders Island, 31 October 1980 (No.13; plate 3)

A mass stranding of 117 animals, unusual in that it involved only eight adult males, the remainder being 103 females and six calves. It appeared that the biggest bull came ashore first, to be followed by the herd, 70 of which were clustered around this animal. Two trail-bike riders, who found the whales while many were still alive, attempted to coax some of the smaller ones back into deep water but they swam back to the beach immediately on release. All the whales eventually died. 


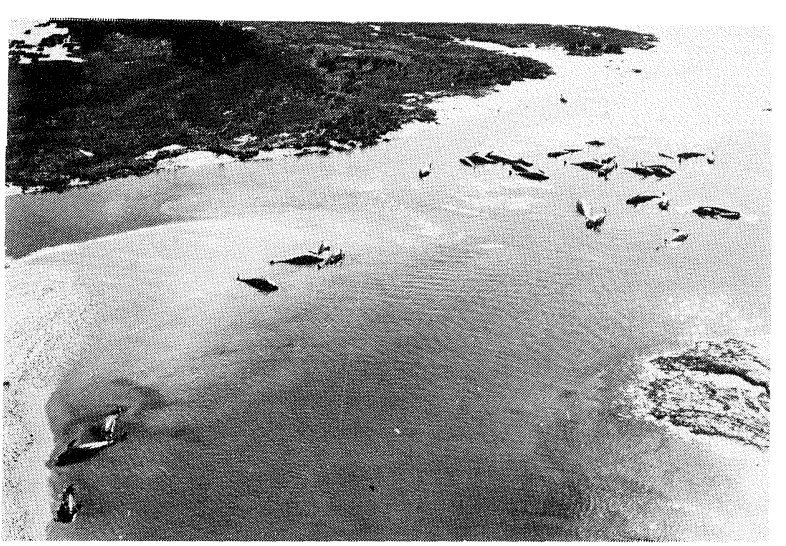

PLATE 3 - Aerial view of stranded Pilot Whales at Patriarchs Inlet (No.13). Photo by courtesy of Mercury, Hobart.
Falmouth, 8 September 1981 (No.22; plates 4 and 5)

A mass stranding of 183 animals. They came ashore at McIntyres Beach, $8 \mathrm{~km}$ south of Falmouth on Tasmania's east coast. One whale was observed to swim away immediately. The rest remained and were accurately counted, the total being 182. A strong off-shore westerly wind was blowing against an easterly swell; the wind continued to strengthen and by midday had reached gale force.

During the afternoon attempts to save some of the whales failed and were eventually abandoned due to the dangerous conditions. By mid-afternoon more than half the whales were dead, including a group of eight mature males at the northern end of the beach thought to have been the first to strand.

Next morning the weather was much calmer. By then, there were carcasses along the length of the beach and floating in the sea nearby. Only 11 whales remained alive. About a third of the bodies were half or three-quarters buried in sand at the water's edge. Carcasses floating in the sea were also inaccessible. As many as possible were sexed (78) and measured (98). The length of the longest measured male was $5.77 \mathrm{~m}$ and the 1 ongest female $4.79 \mathrm{~m}$. The sex ratio was 37 males:41 females. (In a mass stranding of 200 individuals near Dunalley in 1975, recorded by Guiler (1978), the longest male was $6.2 \mathrm{~m}$, the longest female $5.55 \mathrm{~m}$, and the sex ratio 39 males:54 females.)

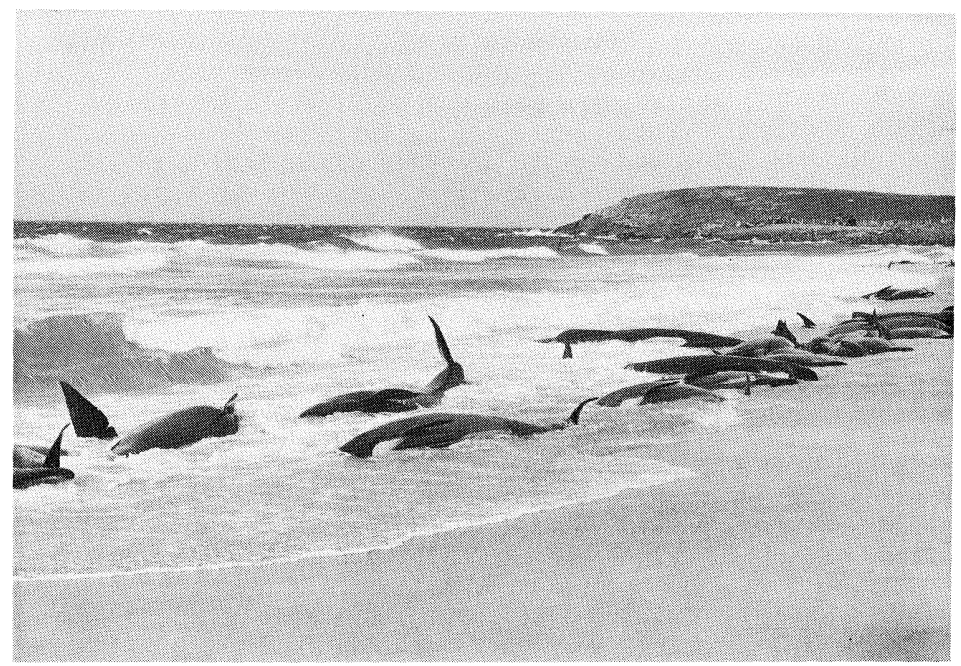

PLATE 4 - Mass stranding of Pilot Whales at Falmouth (No.22) showing rough weather. Photo: A Wapstra. 
T.J. McManus, J.E. Wapstra, E.R. Guiler, B.L. Munday and D.L. Obendorf

The 11 live whales were manhandled back into the sea by members of the public under the direction of "Project Jonah" and Government officers. They joined two whales similarly released during the previous night. It is doubtful whether these animals survived. Subsequent to the stranding, three freshly dead whales were washed onto rocks beyond the northern end of McIntyres Beach on 11 September. Two days later a carcass appeared on Red Bill Beach at Bicheno about $32 \mathrm{~km}$ south. One animal was seen swimming sluggishly off Falmouth on 15 September. Later a $5.1 \mathrm{~m}$ male carcass was discovered on Steels Beach, Falmouth, $2 \mathrm{~km}$ north of the township on 24 October. It had been dead approximately three weeks. Three more freshly dead carcasses were washed ashore at the southern end of McIntyres Beach on 27 September. Finally a decomposed carcass was found on Beaumaris Beach, North Scamander on 4 October. It is believed that at least some of these later strandings involved animals rescued earlier, although there is no proof as they had not been tagged.

The topography of the bay at McIntyres Beach is typical of what has frequently been described as a "whale trap". It is a $1 \mathrm{~km}$ curved stretch of sand flanked by two rocky headlands, Burying Point to the north and Ironhouse Point to the south. About $300 \mathrm{~m}$ due east of Ironhouse Point is a large rocky outcrop above sea level. It is the highest part of a submerged reef which curves inshore and rises to connect with a rocky outcrop extending from the beach. A further submerged reef covered with kelp runs parallel to the beach about $300 \mathrm{~m}$ offshore. An additional hazard in the form of a parallel sandbar is located $100 \mathrm{~m}$ offshore. No cetacean strandings either single or multiple had been recorded there before. However, a year previously, part of a school of dolphins had become temporarily "lost" inside the reef.

Four bulls (from the northern end), plus a cow and calf were autopsied before being buried with the others. The main post mortem findings are tabulated in Appendix 1. An outstanding feature was the presence of large numbers (average 2300, range 1140-4200, number of ears examined 6) of nematode worms Stenurus globicephalae in the ear canals, guttural pouches and auditory sinuses of the four mature males (plate 5). The infestation was accompanied by varying quantities of greyish-white frothy exudate. Very few parasites (142 in left side) were found in the ear passages of the single, mature female which was examined. The presence of water in collapsed lungs of three whales suggested that the final cause of death was drowning.

PLATE 5 - Stenurus nematodes in middle ear cavity of Pilot Whale (No.22). Photo: T.J. McManus.

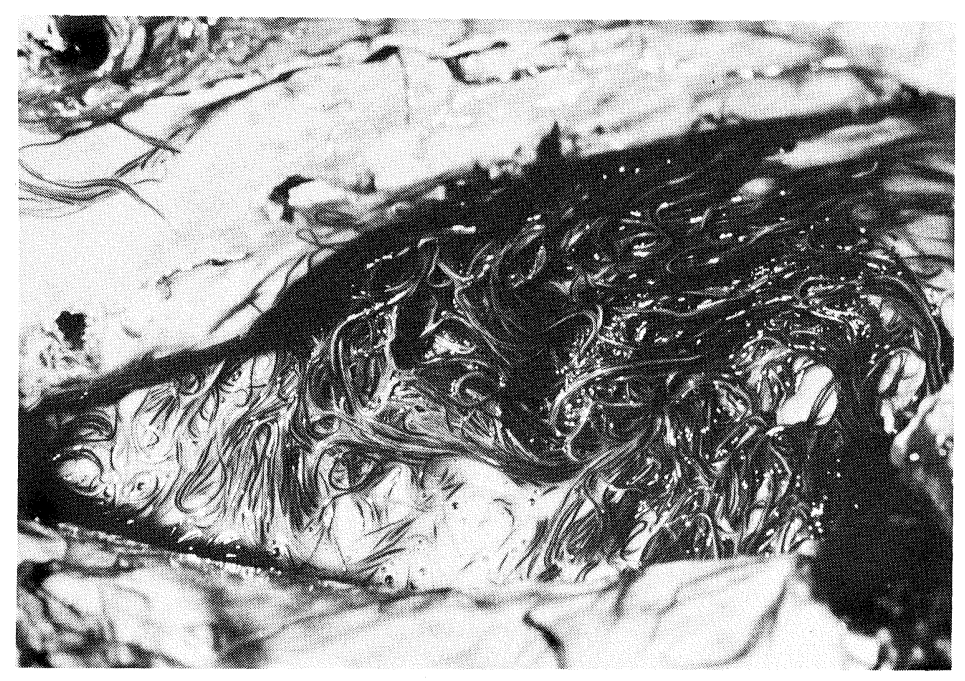


The stomachs of two whales contained beaks of squid or cuttlefish, and eye lenses and otoliths of unidentified fish and/or cephalopods. Results of chemical analyses of organs and tissues are given in Appendix 2 .

Macquarie Harbour, Strahan, 7 January 1982 (No.27)

A mass stranding of 51 animals. The whales appeared to have become "lost" in the network of shallow channels in the harbour. They remained buoyant most of the time and were still partially submerged when periodically stuck on sand bars. Initially the herd was semi-stranded on a sand bar known as Pelican Spit, $2 \mathrm{~km}$ inside the harbour entrance. During the following three days various attempts were made to return the whales to deeper waters in the harbour channels and encourage them to swim out through the harbour mouth. The weather was cool with frequent rain and drizzle which aided the survival of most of the whales.

They seemed generally normal and healthy but were reluctant to move away from a large male which was swimming feebly and appeared weak. One of the ruses employed to coax the whales into deeper water was to tow the sick male and two other bulls by their tailstocks in the hope that the herd would follow. Although this was partially successful it was not until two of the bulls died that the herd became amenable to guidance. On the third day, the herd finally followed a large male being towed backwards for $4 \mathrm{~km}$ towards and through the entrance to Macquarie Harbour. When this animal drowned, the porpoising survivors swam past it and continued out to sea.

In the course of events, blood samples were collected via the lateral tail fluke vein from one immature and four mature female whales. These showed slightly elevated levels of haemoglobin, packed cell volume and blood urea nitrogen compared with other normal eutherians, consistent with the effects of dehydration after two days of alternate partial stranding and aimless swimming in the absence of food. Four out of five creatine phosphokinase estimations of between 140 and 160 units per ml were considered normal, but the fifth from a distressed heavily pregnant female was 660 units, suggestive of muscle damage.

Only one of the dead males was autopsied. It was a large mature animal $4.85 \mathrm{~m} 10 \mathrm{ng}$. In contrast with the situation at Falmouth, only a few $S$. globicephalae nematodes were in its auditory system. Further details are listed in Appendix 1.

The success of the rescue operation was due to the well organised efforts of government officers and volunteers, co-ordinated by the National Parks and Wildife Service. It was the first time that the Service's rescue contingency plan, drawn up following the Falmouth stranding (No.22), was implemented for a mass stranding.

Howells Point, Maria Island, 14 January 1983 (No.40)

A single animal which had been dead for two or three days when found and assumed to have been washed up dead. It was an adult female, $4.35 \mathrm{~m}$ in length. Tissue samples were collected for heavy metal analysis, see Appendix 2.

\section{Killer Whale Orcinus orea}

Sisters Beach, 2 February 1980 (No.9)

This whale came ashore about $6 \mathrm{a} . \mathrm{m}$. Rescue efforts failed due to the rough seas and the animal's bulk. It died that night. The animal was a mature male $6.7 \mathrm{~m} 10 \mathrm{ng}$ and weighed an estimated 10 tonnes. Apart from limited measurements, the only examination was of the tongue in which a single sarcocyst was detected.

It is the first recorded stranding of a Killer whale on Tasmanian shores since 1868 (Guiler 1978) although the species is not uncommon around the coast. Between 1980 and 1982 groups of up to 20 have been regularly observed during the period September-December off the southeastern continental shelf, where they interfered with a newly established longline fishery. A group of 15 was seen by an abalone diver near the Actaeon Islands on 31 January 1983, another group of three was seen by a squid fisherman in the Derwent River not far from Hobart on the night of 3 February 1983. 
T.J. McManus, J.E. Wapstra, E.R. Guiler, B.L. Munday and D.L. Obendorf

Common Dolphin DeZphinus dezphis

Shelley Beach, Orford, 25 October 1977

The animal was freshly dead when found but was not closely examined.

Adventure Bay, South Bruny Island, June 1978 (No.4)

This animal was decomposing when found and not further examined.

Little Taylors Bay, South Bruny Island, about 9 March 1982 (No.32)

Two animals, both about $2 \mathrm{~m}$, dead for approximately two days when found. The

sku11s were collected and retained by the National Parks and Wildlife Service, Hobart.

Ralphs Bay, South Arm, 4 February 1983 (No.45)

A mass stranding, rare for this species, involving 15 animals. As a result of good organisation and rescue equipment (refer stranding number 36) most of the dolphins were rescued within $3 \frac{1}{2}$ hours from the initial alert.

The dolphins were divided into two groups, three adult individuals at South Arm Neck and eight adults and four young about $2 \mathrm{~km}$ further on, towards the South Arm township. The first group was transported to deep water at South Arm and swam off uneventfully. Of the second group, two small calves and one adult were dead and another adult and calf died shortly afterwards. The others were released together at South Arm and swam away. The surviving calf appeared to recognise its mother, as it swam straight to one of the adults, touched its nose and then continued to swim closely beside her.

The three adults of the first group were neither sexed or measured. Of the second group, all the dolphins rescued were females. Two mature females died, but the three calves which died were all males. Samples from the dead dolphins were taken for analysis and all animals in the second group were measured.

Although the tidal mudflats of the South Arm area are a hazard to dolphins as indicated in the Discussion, it is noteworthy that a squid fisherman observed three Killer Whales hunting dolphins in the Derwent River not far from the entrance to Ralphs Bay on the night before the stranding.

Bottlenosed Dolphin Tursiops truncatus

Two Mile Beach, Dunalley, 18/19 February 1975

Two adult dolphins among 200 Pilot whales (Guiler 1978) and overlooked at the time.

Ralphs Bay, South Arm, 10 September 1977

A single animal, identified but not closely examined.

Adventure Bay, South Bruny Island, 27 April 1978 (No.3)

A single animal, identified but not closely examined.

Pittwater, Midway Point, 1 November 1978 (No.6)

Two dolphins stranded high and dry by receding "spring" tide on the extensive mudflats of Five Mile Beach. They were an adult female and her calf, successfully released together at Lauderdale about 8 hours later.

Ralphs Bay, South Arm, 30 September 1980 (No.12)

First observed at about $5 \mathrm{a} . \mathrm{m}$. A mother and her calf were hopelessly stranded on extensive mudflats and were successfully released at South Arm jetty at 9.30 a.m.

Riedle Bay, Maria Island, January 1981 (No.16)

Three decomposing carcasses found in February 1981 at the northern end of the island's isthmus, on the ocean side.

Eaglehawk Neck, Tasman Peninsula, January/February 1981 (No.18)

When discovered this animal had been dead for at least two weeks and was badly decomposed. No measurements were taken and its sex could not be determined. 
Ocean Beach, Strahan, 8 January 1982 (No.28)

An adult female in good condition which swam away five minutes after being returned to the water, 24 hours after stranding in a shallow tidal pool. Overnight rain aided the animal's survival.

Gorringes Beach, South Arm, about 1 April 1982 (No.33)

A male found dead on extensive tidal flats in the same general vicinity as another stranding in May 1964 (Guiler 1978) and from where a mother and calf were rescued on 30 September 1980 (stranding number 12).

Pittwater, Midway Point, 1 October 1982 (No.36)

Virtually the same site as the 1978 stranding of this species (stranding number 6). Pittwater is a large shallow bay with extensive tidal mudflats similar to the South Arm area where strandings are also common. A $2.55 \mathrm{~m}$ male and a $2.70 \mathrm{~m}$ female were found in good condition without blisters or visible ailments.

A feature of this stranding was that it gave National Parks and Wildife Service personnel the first opportunity to test newly acquired rescue equipment, evolved as a result of attempts to rescue Pilot whales at Falmouth (stranding number 22). A special rescue sheet made from non-porous material (PVC "Ripstop"), glided over the wet sand and a "net" of ropes fixed to its edges easily transformed it from a sledge to a stretcher. As a result both animals were released without incident into the surf at Seven Mile Beach township a few kilometres away, less than three hours after the original report of the stranding was received. By contrast the 1978 rescue (stranding number 6) took nearly eight hours.

Seven Mile Beach, about 24 January 1983 (No.42)

This animal was found dead on the seaward side of the long sandspit which forms Pittwater, the site of previous strandings of the species (strandings number 6 and 36 ). It was a $3.4 \mathrm{~m}$ male, but further examination was not possible as the carcass had started to decompose when discovered.

\section{DISCUSSION}

There has been a significant increase in the number of recorded strandings in recent years. During the $5 \frac{1}{2}$ years to 31 May 1983 there were 46 incidents, compared to 28 in the preceding $5 \frac{1}{2}$ years and 106 for the whole of the recorded history of Tasmania as reported by Guiler (1978). It is likely that the increase is a result of improved reporting, rather than a greater abundance of whales or higher frequency of strandings.

In Tasmania, a mass stranding of Pilot whales at Falmouth in 1981 led to the formulation of a contingency plan under which the National Parks and Wildlife Service co-ordinates rescue operations and scientific investigations at strandings. Information flow to the media has been an important part of the contingency plan and local media coverage of strandings, even if they were of an unspectacular nature, has been frequent and excellent. This has served to heighten an already growing public awareness of whales. Dead whales, which probably would have gone unrecorded in the past, are now often reported on the day they are found. One important benefit is that chances of discovery of rare species are improved. The data presented add two species new to Tasmania, Sei whale and Southern Bottlenosed Whale, to the number previously cited by Guiler (1978) and add significantly to scanty information on other species.

Greater mobility of people and improved access to beaches are likely to be major contributing reasons for the increase in recorded strandings. Obviously, if few people visit a particular location, a stranded whale may well go unrecorded as remains can wash away or become buried very quickly by wave or wind action. Examination of table 1 shows that al1 stranding dates except seven (numbers 3, 4, 5, 13, 14, 24 and 46)'fal1 within the summer holidays or other school vacations when there are more people in coastal areas. During the last decade ownership of trail bikes and four-wheel drive vehicles has increased. Beaches which were remote and inaccessible ten years ago are now visited frequently. 


\section{T.J. McManus, J.E. Wapstra, E.R. Guiler, B.L. Munday and D.L. Obendorf}

Only one stranding was reported from the densely populated north and northwest coasts to the east of Stanley. Of the more than 100 previous strandings (Guiler 1978) only 10 occurred along that part of the Tasmanian coast. As beaches and foreshores there would be visited at least as frequently as other coastal areas, it must be concluded that whale strandings between Wynyard and Bridport are rare events. A possible explanation is that the shallow waters of Bass Strait adjacent to the central north coast are not part of the migratory routes of whales.

Reference to figure 1 shows that three locations have had a high number of strandings. These are Perkins Bay (Stanley), Storm Bay (Hobart) and Macquarie Harbour and Ocean Beach near Strahan.

Whales moving south past King Island may find themselves in the western end of Bass Strait. Whilst attempting to leave the area, they face a formidable hazard. The Circular Head Peninsula, with the town of Stanley, juts out into the Strait for a distance of $10 \mathrm{~km}$. Perkins Bay to the west is a large but shallow body of water with shoals, sandbars and channels, semi-enclosed by the peninsula and Perkins and Robbins Islands. Tidal flows are very rapid. The chances of whales employing sonar becoming confused or whales simply being left by a fast receding tide, appear to be high. The latter hazard can be exacerbated if a strong northwesterly wind coincides with an incoming tide and then drops or changes direction, as happened in the case of stranding number 34 . Perkins Bay has been described as a "whale cemetery" by Scott (1942). Of 65 strandings in places with more than one stranding between 1945 and 1977, 12 (18\%) occurred here (Guiler 1978). Of the 46 recent strandings $5(10 \%)$ happened in this relatively small part of the coast.

In the south, a similar hazard is present in Storm Bay, which incorporates the Derwent estuary, Ralphs Bay, Frederick Henry Bay, Pittwater and Norfolk Bay. Storm Bay is a large body of water semi-enclosed by the Tasmanian mainland, North Bruny Island and the Tasman Peninsula. This topographical pattern is repeated many times on a smaller scale within the area. Many of the bays are characterised by extensive tidal flats. Of the 46 recent strandings, $9(20 \%)$ occurred here. Most of these involved dolphins left stranded by the outgoing tide.

A further $5(10 \%)$ of the recent strandings occurred on the west coast near Strahan where Cape Sorell and the southern section of Ocean Beach form a funnel leading into Macquarie Harbour. Rounsevel1 et al. (1981) described this section of coast as treacherous to whales due to the topographical features of the coast and sea bottom.

Together, the above locations occupy less than $10 \%$ of the Tasmanian coast but account for about $40 \%$ of recent strandings. This suggests that, at least in Tasmania, whale trap situations leading to navigational error or the simple misfortune of being left stranded by a fast receding tide, are of significance in causing or contributing to strandings. This is contrary to the findings of Sergeant (1982) who concluded that animals about to strand are in a passive, moribund state drifting to the coastline by currents and who discounted external factors such as coastal configuration.

The "spring" tides caused by gravitational forces at full and new moon, being more extreme with consequently faster tidal flow rates, are likely to exacerbate or even create the hazards described above. Although only 13 of the recent strandings occurred at times of peak tides, this aspect bears further investigation in future as 10 of these strandings happened in summer when such tides are generally stronger than in other seasons.

As elsewhere, herd cohesion in the gregarious toothed whales (causing the herd to beach en masse in response to distress signals emitted by stranded individuals) is believed to have been a factor in at least some mass strandings in Tasmania. In the case of the herd of Pilot Whales entrapped in Macquarie Harbour (number 27), herd cohesion was successfully used in the rescue.

Pathological investigation has only been possible in a relatively small number of the strandings reported here. However, indications to date are that disease has not been a significant factor. Auditory parasitism can compromise navigational abilities under 
adverse conditions (Dailey \& Walker 1978). This appears to have been a significant contributory factor in the mass stranding of Pilot whales at Falmouth (number 22), where the mature males examined (presumed to have been the herd leaders) were found to be severely affected. On the other hand, no significant infestation was found in the Pilot Whales at Macquarie Harbour (number 27) where topographical factors provide a satisfactory explanation for the stranding.

Observations in Tasmania to date do not lend credence to hypotheses (Cordes 1982) such as "attempting to negotiate ancestral pathways now above the waterline", or "an instinctive tendency to return to land when in distress" or even "mass suicide". Human observers have long been puzzled by the apparent deliberateness of whale behaviour at mass strandings, especially the observed tendency of rescued whales to return to the beach. However, there are a number of quite satisfactory explanations for such observed behaviour, including herd cohesion and muscle cramp. The whales rescued at Falmouth (number 22) did not have a tendency to return to the beach, probably because they were unable to communicate with the remaining live whales which were far from the waterline at the time of rescue. Observations on rescued dolphins which had been lying on one flipper for a long time showed a strong tendency to list and swim in circles which led them back to the beach. Once rescuers held these animals in the water for five or ten minutes prior to release, such problems were not experienced. The theory that sick or dying whales may have a tendency to "return" to land to avoid drowning does not stand up to scrutiny. If it were correct, strandings would occur far more frequently.

A great deal more research will be necessary before all strandings can be confidently explained. Tasmania appears to be in an excellent position for such work due to the high frequency of strandings. The Tasmanian contingency plan provides a suitable and increasingly effective framework for co-ordinated research by biologists, pathologists and others. An understanding of the causes of stranding is not only of academic interest, but essential to the success of future rescue operations.

The questions of rescue, euthanasia and disposal of stranded whales are vexed ones also in need of considerably more study.

At Macquarie Harbour and Falmouth, as we1l as a number of rescues in the Hobart area, whales were returned to sea and were seen to swim away. The animals involved were not marked and their eventual fate can only be speculated upon. At Falmouth (number 22) evidence suggests that at least some of the "rescued" Pilot Whales did not survive and similar doubts were raised after the departure of Sperm whales (number 17) from the entrance to Macquarie Harbour. On the other hand, the rescue of pilot whales (number 27) from Macquarie Harbour and a number of dolphin rescues near Hobart (numbers 6, 12, 36 and 45) were not followed by reports of subsequent strandings and these are likely to have been successful.

The National Contingency Plan for Cetacean Strandings (Anderson 1982) states that its primary objective is to return stranded cetaceans to sea. In Tasmania, the actions of authorities are in line with this objective and the State Government has provided a special contingency fund for the purpose. If, as suggested by Geraci \& St Aubin (1979), survival rate is low, the present heavy use of resources may not be justified in certain instances. Further investigations, and above all more experience, are necessary to enable the formulation of firm guidelines which can be enforced by the National Parks and Wildlife Service. These guidelines should indicate when a substantial effort to rehabilitate the whales is warranted or when nothing should be done. They should include appropriate rescue methods, marking, euthanasia and disposal.

Euthanasia is an emotive issue, but experienced researchers agree that it is indicated where the continued survival of individuals prejudices the survival of the herd or when it is physically impossible to return the whales to sea (Geraci \& St Aubin 1979, Mead pers. comm., Cawthorn pers. comm.). Considerable research is needed into practical and acceptable methods of euthanasia for different species (Munday 1983). 
Disposal of carcasses sometimes constitutes a major problem, especially if 1 arge animals or large numbers are involved. To date, deep burial has been the most satisfactory method and modern heavy machines such as bulldozers, backhoes and logskidders have all been utilised for this purpose. It has been suggested locally that carcasses should be used for meat-meal or pet food; however, the level of mercury in the flesh (Appendix 1) makes such use undesirable. Indeed, it will be noted that the Pilot whale washed up on Maria Island (number 40) had a mercury level in its subcutaneous muscle of 6.2 ppm. The maximum safe limit for human consumption of shark flesh, prescribed by Health Departments in Tasmania and South Australia is $1 \mathrm{ppm}$, and $0.5 \mathrm{ppm}$ in the other Australian States.

A hitherto ignored factor likely to influence the recuperation of cetaceans returned to sea is external rhabdomyolysis, also known as "capture myopathy". Regardless of continuing improvements in methods and equipment used at strandings, considerable manhandling will almost always be necessary. Studies into the possible effects of this are therefore essential (Colgrove 1978).

Positive physical identification of every cetacean at a stranding has been widely recognised as an essential procedure and has been incorporated into the National Contingency Plan for Cetacean Strandings (Anderson 1982). It should be implemented in Tasmania. Collection of data other than mere statistics must also receive greater attention. This should include a more professional approach to photographic recording, which should be an integral part of every investigation.

Only by more precise analysis of observed and recorded data will scientific knowledge be enhanced sufficiently to permit improved management of cetacean strandings.

\section{ACKNOWLEDGMENTS}

The authors wish to thank Dr J.K. Ling, Director of the South Australian Museum, Adelaide and Dr D.J. Needham, Adelaide for their helpful advice in the preparation of this paper. The interest and personal efforts of the many staff members of the National Parks and Wildlife Service, especially Rangers in coastal areas, who have assisted with the often unrewarding and unpleasant work on dead and decomposed whales, is gratefully acknowledged.

\section{REFERENCES}

Anderson, G.R.V., 1982: National contingency plan for cetacean strandings. Australian National Parks and Wilalife Service, Occasional Paper, No.6: $9 \mathrm{pp}$.

Bergin, T.J., 1978: Stranded whales and dolphins. Procs of courses for veterinarians, No.36. Post-Graduate Committee in Veterinary Science, University of Sydney: 585-595. Colgrove, G.S., 1978: Suspected transportation-associated myopathy in a dolphin. J.A.V.M.A., 173 (9) : $1121-1123$.

Cordes, D.O., 1982: The causes of whale strandings. N.Z. Vet. J., 30: $21-24$.

Dailey, M.D. \& Walker, W.A., 1978: Parasitism as a factor (?) in single strandings of southern California cetaceans. J. Parasitol., 64 (4): 593-596.

Davies, J.L., 1963: WHALES AND SEALS OF TASMANIA. Tasmanian Museum and Art Gallery, Hobart.

and Guiler, E.R., 1957: A note on the pygmy right whale, Caperea marginata (Gray). Proc. Zool. Soc. Lond., 129: 579-589.

Davis, G. \& Guiler, E.R., 1984: The occurrence of the southern bottlenosed whale in Tasmanian waters. Pap. Proc. R. Soc. Tasm., 118: 103-107.

Geraci, J.R. \& St Aubin, D.J., 1979: Stress and disease in the marine environment: Insights through strandings. In Geraci, J.R. \& St Aubin, D.J. (Eds): BIOLOGY OF MARINE MAMMALS; INSIGHTS THROUGH STRANDINGS. U.S. Dept of Commerce, Nat. Tech. Info. Service, PB-293 890: 223-233.

Guiler, E.R., 1978: Whale strandings in Tasmania since 1945 with notes on some seal reports. Pap. Proc. R. Soc. Tasm., 112: 189-213. , 1984: A young strap-toothed whale in Tasmanian waters. Pap. Proc. R. Soc. Tasm., $118: 65-68$. 
134

Cetacean Strandings in Tasmania from February 1978 to May 1983

Munday, B.L., 1983: Euthanasia of whales. Control and Therapy Notes. Post-Graduate Committee in Veterinary Science, University of Sydney: 1546-1547.

- Green, R.H. \& Obendorf, D.L., 1982: A pygmy right whale Caperea marginata (Gray 1846) stranded at Stanley, Tasmania. Pap. Proc. R. Soc. Tasm., 116: 1-4. Rounsevell, D.E., Pearse, R.J. \& Davis, P., 1981: A mass stranding of sperm whales, Physeter macrocephalus Linnaeus, 1758 at Macquarie Harbour, Tasmania. Vict. Nat., 98: 228-233.

Scott, E.O.G., 1942: Records of Tasmanian Cetacea: No.1. Notes on various strandings at or near Stanley, North Western Tasmania. Rec. Queen Vict. Mus., 1: 27-49.

Sergeant, D.E., 1982: Mass strandings of toothed whales (Odontoceti) as a population phenomenon. Sci. Rep. Whales Res. Inst., 34: 1-47.

Watson, L., 1981: SEA GUIDE TO THE WHALES OF THE WORLD. Hutchinson \& Co., London.

APPENDI $X 1$

PATHOLOGICAL, PARASITOLOGICAL AND MICROBIOLOGICAL FINDINGS

$\begin{array}{llllllllllll}\text { Stranding No. } & 9 & 22 & 22 & 22 & 22 & 22 & 22 & 23 & 26 & 27 & 31\end{array}$

$\begin{array}{lllllllllllll}\text { Species } & 00 & \mathrm{Gm} & \mathrm{Gm} & \mathrm{Gm} & \mathrm{Gm} & \mathrm{Gm} & \mathrm{Gm} & \mathrm{Cm} & \mathrm{M} 1 & \mathrm{Gm} & \mathrm{Pm}\end{array}$

O.orea, G.mazaena, C.marginata, $M$. layardi, $P$. macrocephalus.

Length $\quad 6.7 \quad 5.4 \quad 5.45 \quad 2.6$

$\operatorname{Sex}$

Age $\begin{array}{llll}6.45 \quad 4.53 \quad 4.85 & 10.4 \text { metres }\end{array}$

$\begin{array}{lllllll}0 & \circ & 0 & \circ & \text { क } & 0 & \text { 9 }\end{array}$

$M=$ mature

$J=$ juvenile

Lungs :

Inhalation of seawater

Parasites

Bacteria

Parasites

Bacteria

Inflammation

Stomach :

Parasites

Intestines:

Parasites

$\begin{array}{lll}x_{12} & - & -\end{array}$

$\begin{array}{ll}\mathrm{L} & \mathrm{R} \\ 1600 & 1940\end{array}$

$\begin{array}{lll}\mathrm{x} & \mathrm{x} & - \\ \mathrm{x} & \mathrm{x} & -\end{array}$

L R L L

$\begin{array}{llll}1140 & 2900 & 124 & 4200\end{array}$

$\mathrm{X}$

$\mathrm{x} \quad \mathrm{x}$

Unidentified

${ }^{1}=$ Streptococcus sp.

${ }^{2}=$ Pseudomonas sp.

Stenurus

globicephazae

streptococcus sp.

$\mathrm{X}$

X $\quad \mathrm{X}$

x

Anisakis simplex

$x^{2} \quad x^{3}$
${ }^{1}$ Unidentified cestodes 2Ogmogaster sp.
${ }^{3}$ Bolbosoma
capitatum

Blubber:

Parasites

$\mathrm{X}$

Muscle:

Parasites 
APPENDIX 2

CHEMICAL ANALYSES OF TISSUES

\begin{tabular}{|c|c|c|c|c|c|c|c|c|c|c|c|c|c|c|}
\hline STRANDING No. & (22) & (22) & (22) & (22) & (22) & (22) & $(26)$ & (27) & (31) & (34) & (35) & (40) & (43) & \\
\hline SPECIES & G.m. & G.m. & G.m. & G.m. & G.m. & G.m. & M. 1. & G.m. & P.m. & C.m. & C.m. & G.m. & C.m. & $\begin{array}{l}\text { G. melaena, M. Layardi, } \\
\text { P. macrocephatus, C. marginata }\end{array}$ \\
\hline LENGTH & $5.4 \mathrm{~m}$ & $5.45 \mathrm{~m}$ & $2.6 \mathrm{~m}$ & & & & $4.53 \mathrm{~m}$ & 4.85 & $10.4 \mathrm{~m}$ & $6.0 \mathrm{~m}$ & $6.09 \mathrm{~m}$ & $4.35 \mathrm{~m}$ & $5.0 \mathrm{~m}$ & \\
\hline SEX & $\sigma^{\pi}$ & $\sigma^{\pi}$ & \& & $\sigma^{\pi}$ & $q$ & $\sigma^{7}$ & $q$ & $0^{\top}$ & \& & 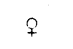 & $0^{\pi}$ & \& & $q$ & \\
\hline AGE & M & M & J & M & M & M & M & M & M & M & M & M & M & $M=$ Mature $\quad J=$ Juvenile \\
\hline \multicolumn{15}{|l|}{ LIVER } \\
\hline$\overline{\mathrm{Pb}}$ & & & & & & & - & - & & & & & & \\
\hline$c d$ & & & & & & & - & 13 & & & & & & \\
\hline $\begin{array}{l}\mathrm{Cu} \\
\mathrm{Zn}\end{array}$ & & & & & & & $\begin{array}{r}2.7 \\
10.0\end{array}$ & $\begin{array}{l}5.6 \\
31\end{array}$ & & & & & & values in ppm \\
\hline \multicolumn{15}{|l|}{ KI DNEY } \\
\hline $\mathrm{Pb}$ & & & & & & & & - & & & & & & \\
\hline$c d$ & & & & & & & & 12 & & & & & & \\
\hline & & & & & & & & 3.0 & & & & & & \\
\hline $\mathrm{Zn}$ & & & & & & & & 22 & & & & & & \\
\hline \multicolumn{15}{|l|}{ BLUBBER } \\
\hline Dieldrin & - & - & - & - & 0.2 & - & 0.1 & & & $\mathrm{t}$ & $\mathrm{t}$ & $\mathrm{t}$ & 0.1 & $\mathrm{t}=$ trace - less than $0.05 \mathrm{ppm}$ \\
\hline D.D.T. & 0.4 & 0.4 & 1.3 & 0.3 & 0.2 & 0.5 & 0.3 & 0.8 & & $\mathrm{t}$ & $\mathrm{t}$ & $\mathrm{t}$ & 0.5 & \\
\hline D.D.E. & 0.5 & 0.5 & 2.8 & 0.5 & 0.4 & 0.9 & 0.3 & 0.5 & & $\mathrm{t}$ & $\mathrm{t}$ & & 0.5 & values in ppm \\
\hline D.D.D. & & & & & & & & & & $\mathrm{t}$ & & & 0.1 & \\
\hline H.C.B. & $\mathrm{t}$ & $\mathrm{t}$ & $\mathrm{t}$ & - & - & $\mathrm{t}$ & & & & & $\mathrm{t}$ & $\mathrm{t}$ & 0.1 & \\
\hline Lindane & & & & & & & & & & & & - & $\mathrm{t}$ & \\
\hline \multicolumn{15}{|l|}{ BRAIN } \\
\hline Dieldrin & $\mathrm{t}$ & & & & & & & & & & & & & \\
\hline D.D.T. & - & & & & & & & & & & & & & \\
\hline D.D.E. & $\mathrm{t}$ & & & & & & & & & & & & & \\
\hline H.C.B. & & & & & & & & - & & & & & & \\
\hline \multicolumn{15}{|l|}{ MUSCLE } \\
\hline$\overline{\mathrm{Hig}^{-}}$ & 1.89 & & 0.29 & 0.31 & & 1.29 & 1.17 & 1.66 & 0.61 & & 0.03 & 6.2 & & values in ppm \\
\hline
\end{tabular}

